\title{
THE SOIL SEED BANK DURING ATLANTIC FOREST REGENERATION IN SOUTHEAST BRAZIL
}

\author{
BAIDER, C., ${ }^{1}$ TABARELLI, M. ${ }^{2}$ and MANTOVANI, W. ${ }^{1}$ \\ ${ }^{1}$ Departamento de Ecologia Geral, Universidade de São Paulo, CEP 05408-400, São Paulo, SP, Brazil \\ ${ }^{2}$ Departamento de Botânica, Universidade Federal de Pernambuco, CEP 50670-901, Recife, PE, Brazil \\ Correspondence to: Marcelo Tabarelli, Departamento de Botânica, Universidade Federal de Pernambuco, \\ CEP 50670-901, Recife, PE, Brazil, e-mail: mtrelli@npd.ufpe.br \\ Received October 25, 1999 - Accepted March 21, 2000 - Distributed February 28, 2001
}

(With 2 figures)

\begin{abstract}
A survey was conducted to determine the density and species composition of viable seeds buried in four stands of a tropical montane forest at Parque Estadual Intervales, Brazil. The objective was to understand: (1) how numbers and composition of the soil seed bank change as the forest regrows, and (2) how such changes affect the species available for regeneration if forests of different ages are cut down. In each forest stand $(5,18,27$-yr-old and a mature forest), 57 soil samples were collected ( 0 2.5 and $2.5-5 \mathrm{~cm}$ deep). Viable seed density of herbaceous species ranged between 11,003 seeds. $\mathrm{m}^{-2}$ (5-yr-old vegetation) and 482 (mature forest), and between 25 (5-yr-old vegetation) and 389 seeds. $\mathrm{m}^{-2}$ (mature forest) for woody plant species in the $0-5 \mathrm{~cm}$ soil layer, suggesting a decrease in seed stocks in the course of forest regeneration. Seeds buried in the $0-2.5 \mathrm{~cm}$ soil layer represented between $56.9 \%$ and $67.4 \%$ of all viable seeds. Most of the viable seeds belonged to weeds of Asteraceae, Poaceae, Malvaceae and Solanaceae. The results provide evidence that, in forests of different ages, the soil does not store seeds of the same key ecological groups involved in the regeneration of Atlantic forest. Allochthonous seeds from remaining patches of forest, as well as their vertebrate dispersers, are needed for forest regeneration since the soil seed bank does not store large seeds of shade-tolerant species.
\end{abstract}

Key words: Atlantic Forest, Brazil, forest regeneration, pioneer species, soil seed bank.

\section{RESUMO}

\section{O banco de sementes do solo durante a regeneração da floresta Atlântica no sudeste do Brasil}

Este estudo foi realizado com a finalidade de determinar a densidade de sementes viáveis e a composição de espécies no banco de sementes de quatro trechos de Floresta Atlântica com diferentes idades no Parque Estadual Intervales, SP. Duas questões foram abordadas: (1) como o número e a composição de espécies muda ao longo do tempo e (2) quais as implicações dessas mudanças para o processo de regeneração da floresta após corte e queima. Em cada trecho de floresta (5, 18, 27 anos e floresta madura), 57 amostras de solo foram coletadas entre 0 e $5 \mathrm{~cm}$ de profundidade. A densidade de sementes viáveis das espécies herbáceas variou entre 11.003 (vegeteção com 5 anos) e 482 sementes $/ \mathrm{m}^{2}$ (floresta madura); e a das espécies lenhosas entre 25 (vegeteção com 5 anos) e 389 sementes $/ \mathrm{m}^{2}$ (floresta madura). As densidades encontradas sugerem um decréscimo no estoque de sementes no solo com o avanço da regeneração. Sementes enterradas entre 0 e $2,5 \mathrm{~cm}$ de profundidade representaram entre $56,9 \%$ e $67,4 \%$ das sementes. A maioria das sementes pertence a plantas invasoras das famílias Asteraceae, Poaceae, Malvaceae e Solanaceae. Os resultados encontrados são evidências de que a contribuição do banco de sementes para a regeneração da floresta depende da idade em que esta é cortada. Sementes oriundas de outras fontes são necessárias para a regeneração, já que o banco não armazena sementes médias e grandes das espécies lenhosas tolerantes à sombra.

Palavras-chave: banco de sementes, Brasil, espécies pioneiras, Floresta Atlântica, regeneração de florestas. 


\section{INTRODUCTION}

Relatively few studies have determined the factors that affect the regeneration of tropical forests after human disturbance, yet a better understanding of these factors could help to develop ways to restore these important habitats (Duncan \& Chapman, 1999). Nowadays, as in the past, shifting agriculture (slash-and-burn, sensu Uhl, 1982) is probably the most important cause of deforestation and it is practiced everywhere in the humid tropics and subtropics, except in Australia and a few regions where local conditions allowed sedentary agriculture (Richards, 1996). Knowledge of the soil seed bank might be especially important to understanding regeneration because forest cleared for shifting agriculture has three potential sources of regeneration: seeds present in the soil at the time of disturbance, post-disturbance seed input, and resprouting trunks and roots (Young et al., 1987).

According to Putz \& Appanah (1987) and Lawton \& Putz (1988), 85\% of woody plant establishment in the early regeneration of two tropical forests after shifting agriculture was related to viable seeds in the soil bank. In contrast, soil seed bank is not a mechanism of major importance in regeneration of lowland Amazonian forests at sites abandoned after long-term (i.e., > 5 years) land use (Uhl, 1982). In this situation, seed immigration from forest remnants is needed. These remnants represent available habitats for pioneers, shadetolerant species and for their vertebrate dispersers inside human-managed landscapes (Nepstad et al., 1995).

The Brazilian Atlantic Forest is one of the most threatened ecosystems in the world (Ranta et al., 1998). The $7.5 \%$ that remains of this forest in southeast Brazil (Myers et al., 2000) is represented to a large extent by secondary forests (Brown \& Brown, 1992), part of it is under longterm land use for agriculture with very short fallow periods (i.e., 3-10 years) (Oliveira et al., 1994). As stated by Uhl (1982), in all types of tropical forest very little is known about regeneration after long-term land use, despite its importance for land management and biological conservation (Nepstad et al., 1991, 1998). In this study we evaluated the density of viable seeds and species composition of the seed bank in four stands of different ages in the Atlantic montane forest. We ask two questions: (1) how do numbers and composition of the soil seed bank change as the forest regrows after long-term land use? (2) How do such changes affect the species available for regeneration if forests of different ages are cut?

\section{MATERIAL AND METHODS}

\section{Study area}

The study was conducted at Parque Estadual Intervales $\left(24^{\circ} 12^{\prime} \mathrm{S}, 4^{\circ} 03^{\prime} \mathrm{W}\right)$, a 38,536 -ha reserve of Atlantic Forest, State of São Paulo, southeast Brazil (Fig. 1). It is located in the Paranapiacaba mountains, at elevations ranging between 60 and 1,100 m (Almeida, 1974). In the study region the predominant soils are oxisols and podsols (Comissão de Solos, 1960). According to Koeppen's classification, the regional climate is humid-temperate, lacking a demarcated dry season. Mean rainfall throughout this area is approximately $1,720 \mathrm{~mm}$. $\mathrm{yr}^{-1}$, with the wettest and the driest period of the year between December and March, and July and August, respectively (São Paulo, 1972). The primary vegetation in this region is best classified as tropical montane rain forest, which is often considered to be one of the major Atlantic Forest types in Brazil (Veloso et al., 1991).

The Atlantic Forest in the study area presents a woody plant species composition similar to the other Atlantic montane forest sites described in the literature. Myrtaceae, Lauraceae, Rubiaceae, Melastomataceae and Leguminosae are usually the richest woody plant families (Mantovani et al., 1990; Tabarelli, 1997).

\section{Soil seed bank}

Using information from local people and the analysis of aerial photos, three 0.2-ha stands of forest aged 5, 18 and 27 years, and a 0.2-ha stand of a mature forest were selected. All of them situated in similar conditions of topography (900 m above sea level). All stands were surrounded by early secondary forests, farm sites and mature forests. In such places shrubs and pioneer trees of the Asteraceae, Euphorbiaceae, Solanaceae were abundant, as were weeds of the Poaceae, Cyperaceae and Malvaceae. The stands of secondary forest were considered representative of the regeneration process as the mature forest was cut down and the land used for shifting agriculture (Baider, 1994). 


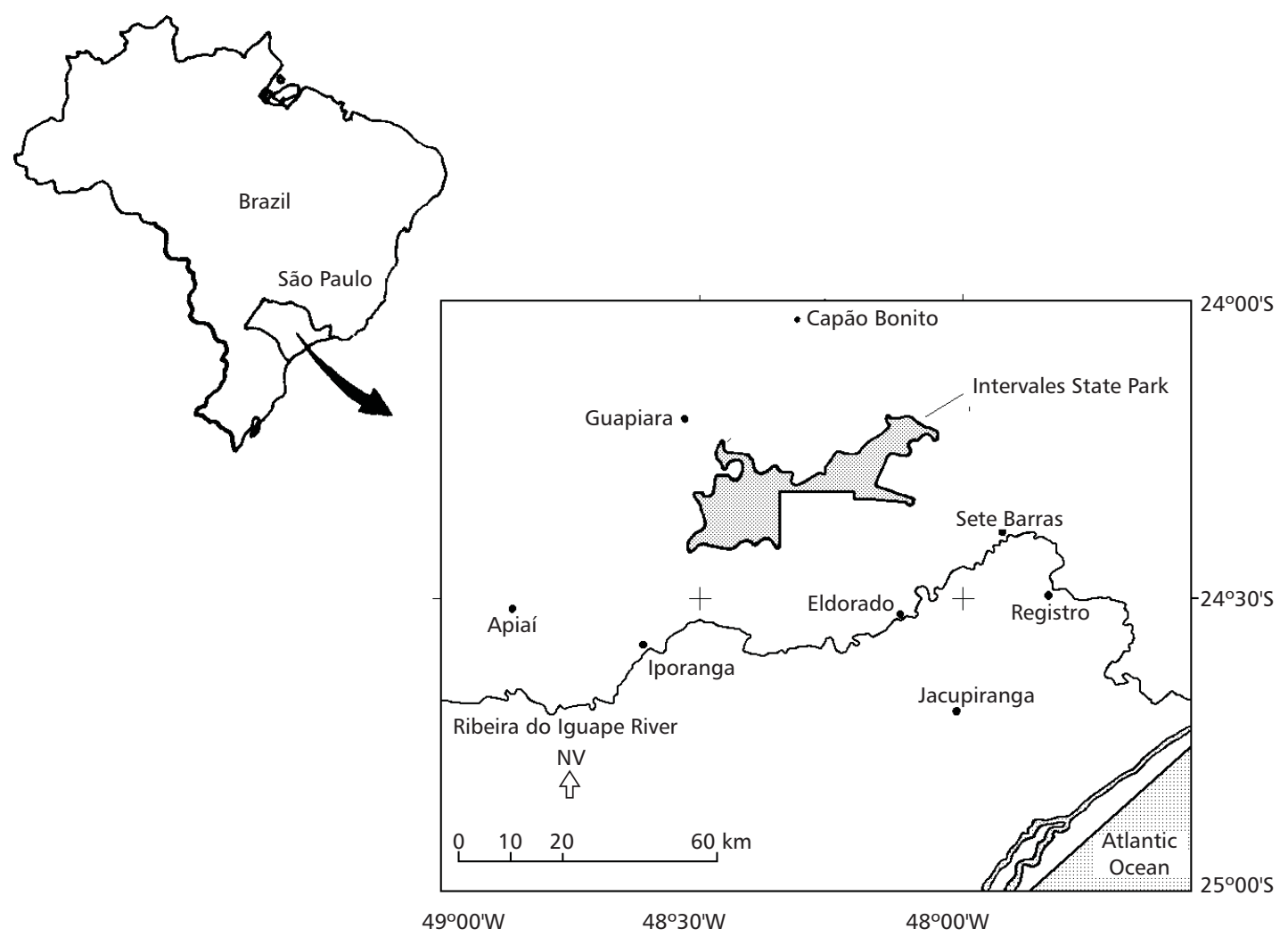

Fig. 1 - Location of Intervales State Park, Brazil.

The most common crops planted were manihot (Manihot esculenta), potatoes, and maize. According to Nascimento (1994), the stands were used for at least 5 years before being abandoned, characterizing a type of long-term land use (sensu Uhl, 1982). Stands probably suffered multiple clearings since the original mature forest was first cut.

In order to investigate the density, species richness and composition of viable seeds in the soil, 57 soil samples were taken randomly at each stand of forest from two soil layers (0-2.5 and 2.5$5 \mathrm{~cm}$ deep) in the same column of soil. The samples sizes were $2.5 \mathrm{~cm}$ deep and $11.3 \mathrm{~cm}$ diameter. The soil samples were transferred to plastic pots that were maintained under field conditions at Universidade de São Paulo, city of São Paulo.

According to Koeppen's classification, the climate in São Paulo is humid-temperate, lacking a demarcated dry season. Mean rainfall is approximately $1,400 \mathrm{~mm} \mathrm{yr}^{-1}$, with the wettest and the driest period of the year between December and March, and July and August, respectively (São Paulo, 1972). Eight pots with sand were randomly distributed in the same location to control seed contamination. Emerging seedlings 30 to 60-dayold were collected and identified by botanical specialists at Universidade de São Paulo. After a 60-day period, the soil with no recruitment was turned upside down in order to expose covered seeds to light. Plant recruitment was monitored for 17 months (January 1992 to May 1993). The number of seedlings recorded was used to estimate: (1) the density of viable seeds for each stand of forest, and (2) the density for each layer of soil.

The tree and shrub species identified were classified in functional groups (hereafter, guilds) according to mutually exclusive categories describing the following life-history traits: Regeneration niche - (1) the shade-intolerant, including species which regenerate only in natural gaps (Hartshorn, 1978), as well as species which rege- 
nerate either in natural gaps or below the pioneer forest canopy, referred as large pioneers by Swaine \& Whitmore (1988); (2) shade-tolerant, including the species which regenerate in treefall gaps and below the mature forest canopy (Hartshorn, 1978). Seed-dispersal - (1) zoochoric species: those producing diaspores attached to a fleshy pulp, aril, or other features typically associated with vertebrate dispersal agents; (2) anemochoric species: those presenting winged seeds, plumes, or other wind-dispersal devices that slow the rate of seed fall; and (3) autochoric species: those dispersed entirely by free fall or propelled explosively by a fruit that opens suddenly or by a trip-lever (Pijl, 1982). Anemochoric and autochoric species could then be grouped into a single category comprising all species dispersed by abiotic mechanisms. Zoochoric species were also classified into two size classes of diaspores: (1) seeds shorter than $1 \mathrm{~mm}$ length, and (2) those between 1 and $10 \mathrm{~mm}$ length. Species were classified into these guilds based on the distribution of their seedlings in gaps or in the forest understory (Mantovani, 1993; Tabarelli \& Mantovani, 1997), and information about their regeneration strategies and seed morphology published by Reitz (1989) and Roosmalen (1985).

\section{Data analysis}

We examined the correlation between forest age and (1) total density plant of viable seeds. $\mathrm{m}^{-2}$; and (2) the number of woody species in the seed bank, using Spearman rank correlation coefficients (Siegel, 1979). For these analyses, we considered the mature forest as 120 years old. This is the period required for Atlantic Forest regeneration after shifting agriculture (Klein, 1980). Number of viable seeds was compared between soil layers and among growth forms (herbaceous vs. woody plant species) with Qui-squared tests (Siegel, 1979). The analyses were carried out using the SYSTAT 7.0 software package.

\section{RESULTS}

\section{Seed density}

Viable seed density of herbaceous species ranged between 11,003 (5-yr-old vegetation) and 482 seeds. $\mathrm{m}^{-2}$ (mature forest), and between 25 (5yr-old vegetation) and 389 seeds. $\mathrm{m}^{-2}$ (mature forest) of woody plant species.

Thus, the soil seed bank stored between 11,028 to 872 viable seeds. $\mathrm{m}^{-2}$, depending on forest age (Table 1).

TABLE 1

Density of viable seeds buried in two different soil layers for each stand of forests at Intervales State Park.

\begin{tabular}{|c|c|c|c|c|}
\hline Forest stand/soil layer & $\begin{array}{l}\text { Herbaceous species } \\
\quad\left(\text { seeds per } \mathbf{m}^{2}\right)\end{array}$ & $\begin{array}{l}\text { Woody species } \\
\left(\text { seeds per } \mathbf{m}^{2} \text { ) }\right.\end{array}$ & $\begin{array}{l}\text { Total density } \\
\left(\text { seeds per } \mathbf{m}^{2}\right)\end{array}$ & $\begin{array}{c}\% \text { of total } \\
\text { seeds per } \mathbf{m}^{2}\end{array}$ \\
\hline \multicolumn{5}{|l|}{ 5-yr-old } \\
\hline $0-2.5 \mathrm{~cm}$ & 7,421 & 17 & 7,438 & 67.4 \\
\hline $2.5-5.0 \mathrm{~cm}$ & 3,582 & 8 & 3,593 & 32.6 \\
\hline Total & 11,003 & 25 & 11,028 & - \\
\hline \multicolumn{5}{|l|}{ 18-yr-old } \\
\hline $0-2.5$ & 2,762 & 149 & 2,912 & 62.7 \\
\hline $2.5-5.0$ & 1,613 & 119 & 1,732 & 37.3 \\
\hline Total & 4,375 & 268 & 4,644 & - \\
\hline \multicolumn{5}{|l|}{ 27-yr-old } \\
\hline $0-2.5$ & 2,747 & 158 & 2,905 & 56.9 \\
\hline $2.5-5.0$ & 2,068 & 126 & 2,195 & 43.1 \\
\hline Total & 4,815 & 284 & 5,100 & - \\
\hline \multicolumn{5}{|l|}{ Mature forest } \\
\hline $0-2.5$ & 316 & 251 & 567 & 65 \\
\hline $2.5-5.0$ & 167 & 138 & 305 & 35 \\
\hline Total & 482 & 389 & 872 & - \\
\hline
\end{tabular}


As the forest became older, (1) a decrease in the total density of viable seeds, (2) a decrease in the density of viable seeds of herbaceous species, and (3) an increase in the density of viable seeds of woody plant species were observed. Although buried seeds occurred in a decreasing density along forest regeneration, such decrease was not proportional to the increase in forest age $\left(r_{s}=-0.8\right.$, $N=4, \mathrm{p}>0.05)$.

The seed banks were dominated by herbaceous species $\left(X^{2}=7,290.7\right.$, d.f. $\left.=1, \mathrm{p}<0.001\right)$, and most of viable seeds were buried in $0-2.5 \mathrm{~cm}$ soil layer $\left(X^{2}=570.68\right.$, d.f. $\left.=1, \mathrm{p}<0.001\right)$.

\section{Species composition and richness}

Considering the samples from the four stands of forest, 12,337 seedlings emerged during a period of 17 months. Among the 11,786 seedlings of herbaceous taxa (grasses, forbs and sedges), 111 morphotypes (presumably different species) within 28 families were identified. The greater part of these taxa consisted of short-lived weeds of the Asteraceae, Poaceae, Malvaceae and Solanaceae, accounting for $45 \%, 15.3 \%, 5.4 \%$ and $5.4 \%$ of morphotypes identified, respectively.

The remaining 551 seedlings were classified in 27 woody plant species plus two unidentified woody taxa (Table 2). The Melastomataceae was the richest family, accounting for $41.3 \%$ of total species and for $82.5 \%$ of total seedlings, followed by the Euphorbiaceae, Solanaceae and Myrsinaceae. Seventy seven percent of woody plant species were pioneers and $23 \%$ were shade-tolerant ones. Pioneer species represented $96.5 \%$ of seedlings, the remaining $3.5 \%$ being the shade-tolerant ones. The majority of woody plant species recorded $(85.1 \%)$ were vertebrate-dispersed, $55.5 \%$ of them presenting diaspores less than $1 \mathrm{~mm}$ length (Table 2). A positive correlation between forest age and woody plant species richness in the seed bank was found, increasing from four species in 5-yr-old vegetation up to 19 in the mature forest (Fig. 2).

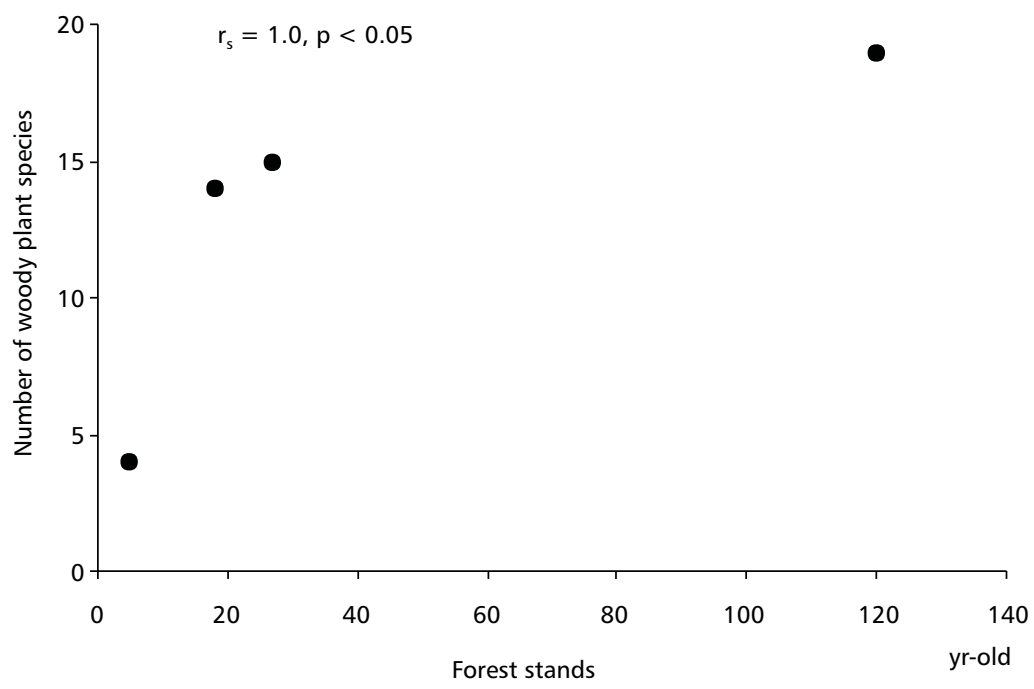

Fig. 2 - Correlation between forest age and the number of woody plant species recorded in the soil seed bank at Intervales State Park, SP.

\section{DISCUSSION}

\section{Seed bank}

Our study area presented a high number of viable seeds buried in the soil (from 872 seeds. $\mathrm{m}^{-2}$ to 11,028 seeds. $\mathrm{m}^{-2}$ ). According to Garwood
(1989), buried seeds in old secondary tropical forests range between 25 and 3,350 seeds. $\mathrm{m}^{-2}$, averaging 383 seeds. $\mathrm{m}^{-2}$. Young et al. (1987) estimated 6,800 viable seeds. $\mathrm{m}^{-2}$ in the soil of a 3.3-yr-old vegetation, 9,500 seeds in 11-yr-old vegetation, and 7,000 seeds. $\mathrm{m}^{-2}$ in a 75-yr-old tropical forest. 
In addition, our results provide evidence that, as forest regeneration proceeds, there is a decrease in the density of viable seeds. Such high density and the changes in numbers and composition of the soil seed bank as the forest regrows is related to herbaceous species. They accounted for the majority of seedlings found and their densities decreased sharply during forest regeneration (Table 2). Although studies by Hopkins \& Graham (1983, 1984) and Vásquez-Yanes \& Orozco-Segovia (1987) pointed out that herbaceous species are not well represented in tropical forest, they are common in the early secondary forests (Gómez-Pompa \& Vázquez-Yanes, 1981; Gómez-Pompa et al., 1991). Herbaceous species recorded in the soil seed bank of tropical forests are generally light demanding pioneers. That is the same pattern found at our study area as most of species belongs to Vernonia, Ambrosia, Eupatorium, Solanum and Sida, very common genera in recently abandoned fields (personal observation). As forest regrowth is accompanied by a decrease in light availability in the forest understory, it is reasonable to suppose that pioneer herbaceous species are not able to produce new seed crops, causing a decrease in seed bank stocks, such as observed in the study area.

Woody plant species contributed little to the soil seed bank (Table 2) and their seed density increased during forest regeneration. Pioneer trees and shrubs are usually recorded in the soil seed bank of tropical forests, representing between $18 \%$ and 91\% of seeds (Enright, 1985; Lawton \& Putz, 1988; Hopkins et al., 1990). In Barro Colorado, Panama, Dalling et al. (1998) recorded 22 tree species in the soil seed bank of a mature forest. Most of them were pioneer species with small seeds $(<20 \mathrm{mg})$ and dispersed by vertebrates. In this study, pioneer trees and shrubs were represented by Alchornea triplinervia, Pera glabrata, Hyeronima alchornioides, Tibouchina mutabilis, Leandra mosenii and Miconia pyrifolia. All of them are very abundant in early Atlantic secondary forests (10-45 years old) (Leitão Filho, 1993; Tabarelli \& Mantovani, 1999b). Alchornea, Piper, Miconia, Leandra and Rapanea species are usually dispersed by generalist birds (manakins, teenagers) and in the case of Solanum species by frugivorous bats (Roosmalen, 1985; Stiles \& Rosselli, 1993; Sick, 1997).

Therefore, we stated that establishment of short and long-lived pioneers at the earliest stages of forest regeneration is responsible for the increase in both seed density and richness of woody plant species in the soil seed bank. Like other tropical forest sites (Holthuijzen \& Boerboom, 1982; Roizman, 1993; Richards, 1996), the majority of seeds are buried to a depth of 2.5, although there are viable seeds buried to at least $5 \mathrm{~cm}$ deep.

\section{Implication for forest regeneration}

Following shifting agriculture, Atlantic Forest regeneration, like any kind of tropical Forest, is characterized by replacement of species showing different life histories and growth forms (Tabarelli \& Mantovani, 1999b). In southeast Brazil, this process could be described as a sequence of seral stages dominated by Andropogon species (grasses), Baccharis (shrubs), Rapanea, Miconia and Alchornea (trees) (Klein, 1980); or by Imperata (grasses), Baccharis, Tibouchina and Alchornea (Tabarelli, 1997) or by Imperata, Baccharis, Tibouchina and Nectandra (tree), as observed in the study area by Nascimento (1994). These species constitute the early or pioneer communities, which are essential for the establishment of shade-tolerant trees and consequently forest regeneration (Tabarelli, 1997).

Essentially, if forests of different ages are cut and used for agriculture, diaspores of different ecological groups (i.e., Baccharis, Tibouchina and Nectandra species) will be available for regeneration (see Table 2). The seed bank in 5-yr-old forest lack any woody plant species involved in forest regeneration.

In contrast, the soil seed bank of the mature forest stores seeds of at least four taxonomic and ecological groups: specifically, pioneer shrubs of the genera Leandra and Miconia, short-lived pioneer trees of Solanum, Rapanea and Tibouchina and long-lived pioneer trees of Alchornea, Hyeronima and Pera. A logical prediction drawn from these results is that under long-term land use with very short fallow periods (i.e., 3-10 years), soil seed bank will have a diminished importance as source of woody plants for forest regeneration.

If the soil seed bank has different contributions for Atlantic Forest regeneration in terms of ecological groups, in contrast the species composition of buried seeds suggests that the seed bank is not important for the restoration of woody plant species richness. 
TABLE 2

Woody plant species and their regeneration strategy $(\mathbf{P}=$ pioneer, $\mathbf{S}=$ shade-tolerant $)$, dispersal strategy (A = abiotic, $\mathrm{V}=$ vertebrate), diaspore length $(\mathrm{M}=<1 \mathrm{~mm}, \mathrm{G}=1<10 \mathrm{~mm})$ and the number of seedlings recorded in the soil seed bank for each stand of forest at Intervales State Park (A = 5 years, B = 18 years, $\mathrm{C}=27$ years old, $\mathrm{D}=$ mature forest).

\begin{tabular}{|c|c|c|c|c|c|c|c|}
\hline \multirow{2}{*}{ Species } & \multirow{2}{*}{ Reg* } & \multirow{2}{*}{ Dis* } & \multirow{2}{*}{ Dia* } & $\mathbf{A}$ & B & $\mathbf{C}$ & D \\
\hline & & & & \multicolumn{4}{|c|}{ (n. of seedlings) } \\
\hline \multicolumn{8}{|l|}{ Clethraceae } \\
\hline Clethra scabra Pers. & $\mathrm{P}$ & A & M & 1 & & & \\
\hline \multicolumn{8}{|l|}{ Compositae } \\
\hline Vernonia discolor Baker & $\mathrm{P}$ & A & M & & 2 & & \\
\hline \multicolumn{8}{|l|}{ Euphorbiaceae } \\
\hline Alchornea glandulosa Poeppig & $\mathrm{P}$ & $\mathrm{V}$ & $\mathrm{G}$ & & 2 & & 3 \\
\hline Croton floribundus Spreng. & $\mathrm{P}$ & A & G & & & 4 & \\
\hline Hyeronima alchornioides Fr. Allem. & $\mathrm{P}$ & $\mathrm{V}$ & G & & & & 2 \\
\hline Pera glabrata (Schott.) Baill & $\mathrm{P}$ & $\mathrm{V}$ & $\mathrm{G}$ & & & & 1 \\
\hline \multicolumn{8}{|l|}{ Flacourtiaceae } \\
\hline Casearia sylvestris $\mathrm{Sw}$. & $\mathrm{T}$ & $\mathrm{V}$ & G & & 4 & & \\
\hline \multicolumn{8}{|l|}{ Melastomataceae } \\
\hline Leandra aff. alterninervia Cogn. & $\mathrm{P}$ & $\mathrm{V}$ & M & & 26 & 53 & 23 \\
\hline Leandra hirtella Cogn. & $\mathrm{P}$ & $\mathrm{V}$ & $\mathrm{M}$ & & 26 & 25 & 2 \\
\hline Leandra mosenii Cogn. & $\mathrm{P}$ & $\mathrm{V}$ & $\mathrm{M}$ & & 28 & 42 & 53 \\
\hline Leandra niangaeformis Cogn. & $\mathrm{P}$ & $\mathrm{V}$ & M & & 24 & 9 & 18 \\
\hline Leandra aff. purpurascens Cogn. & $\mathrm{P}$ & $\mathrm{V}$ & $\mathrm{M}$ & & & & 36 \\
\hline Leandra reversa Cogn. & $\mathrm{P}$ & $\mathrm{V}$ & $\mathrm{M}$ & & & 1 & \\
\hline Leandra aff. reversa Cogn. & $\mathrm{P}$ & $\mathrm{V}$ & M & & 2 & & \\
\hline Miconia pyrifolia Naod. & $\mathrm{P}$ & $\mathrm{V}$ & M & & & & 2 \\
\hline Miconia theaezans (Bompl.) Cogn. & $\mathrm{P}$ & $\mathrm{V}$ & M & & 8 & 2 & 41 \\
\hline Tibouchina mutabilis Cogn. & $\mathrm{P}$ & A & M & & 8 & 5 & 10 \\
\hline sp. 1 & & & & & & & 3 \\
\hline sp. 2 & & & & & & & 8 \\
\hline \multicolumn{8}{|l|}{ Moraceae } \\
\hline Ficus insipida Willd. & $\mathrm{T}$ & $\mathrm{V}$ & $\mathrm{M}$ & & & 1 & \\
\hline Ficus aff. luschnatiana Miq. & $\mathrm{T}$ & $\mathrm{V}$ & $\mathrm{M}$ & & & & 2 \\
\hline \multicolumn{8}{|l|}{ Myrsinaceae } \\
\hline Cybianthus brasiliensis (Mez.) Agost. & $\mathrm{T}$ & $\mathrm{V}$ & G & & & & 1 \\
\hline Rapanea ferruginea (Ruiz et Pav.) Mez. & $\mathrm{P}$ & $\mathrm{V}$ & $\mathrm{G}$ & & 6 & 7 & 4 \\
\hline \multicolumn{8}{|l|}{ Myrtaceae } \\
\hline Eugenia florida D.C. & $\mathrm{T}$ & $\mathrm{V}$ & G & 6 & & 4 & \\
\hline \multicolumn{8}{|l|}{ Rubiaceae } \\
\hline Psychotria stachyoides Benth. & $\mathrm{T}$ & $\mathrm{V}$ & M & & & & 1 \\
\hline \multicolumn{8}{|l|}{ Solanaceae } \\
\hline Cestrum schlechtendalii D.Don & $\mathrm{P}$ & $\mathrm{V}$ & G & & & 1 & \\
\hline Solanum erianthum D. Don & $\mathrm{P}$ & $\mathrm{V}$ & G & & 6 & 1 & 10 \\
\hline Solanum inaequale Vell. & $\mathrm{P}$ & $\mathrm{V}$ & G & 5 & 2 & 4 & 2 \\
\hline \multicolumn{8}{|l|}{ Ulmaceae } \\
\hline Trema micrantha Blume & $\mathrm{P}$ & $\mathrm{V}$ & $\mathrm{G}$ & 2 & 9 & 3 & \\
\hline
\end{tabular}

* Reg = regeneration strategy; Dis = dispersal strategy; Dia = diaspore length. 
Number of tree species $(\geq 10 \mathrm{~cm} \mathrm{dbh})$ in neotropical forest ranges from 118 to 307 species ha ${ }^{-1}$ (Gentry, 1988; Valencia et al., 1994) accounting for at least $50 \%$ of woody plant species richness (Gentry \& Emmons, 1987). In a 1-ha plot of Atlantic Forest, Tabarelli \& Mantovani (1999a) recorded 136 tree species $(\mathrm{dbh} \geq 10 \mathrm{~cm})$. The majority of woody plant species in the forest studied by these authors, as well as in the present study area, are shade-tolerant trees within Myrtaceae, Lauraceae, Sapotaceae, Monimiaceae and Leguminosae (Nascimento, 1994; Tabarelli \& Mantovani, 1999b), with diaspores larger than $5 \mathrm{~mm}$ (cf. Reitz, 1989). No shade-tolerant species with large seeds were recorded in the soil seed bank independently of forest age (see Table 2).

Thus, we postulate that in the Atlantic Forest, post-disturbance inputs of allochthonous diaspores from remaining secondary or mature patches of forest, as well as their vertebrate dispersers, are required. Such patches will provide some of the diaspores required for forest regeneration after land use and abandonment. According to Tabarelli et al. (1993), at sites where seeds and dispersal agents are available in surrounding mature forests, small stands (i.e., 0.2 ha) of 18-yr-old forests can support more than fifty forest species among pioneer and shade-tolerant trees and shrubs (e.g., Euphorbiaceae, Myrtaceae, Lauraceae and Leguminosae species), despite previous long-term land use. As previously detected in the Amazonian region by Silva et al. (1996) at landscapes where shifting agriculture or ranching are the predominant activities, it is essential to protect remnants of forest to maintain the sources of diaspores and the vertebrate dispersers required for regeneration.

In conclusion, our results provide evidence that numbers and composition of the soil seed bank change as the forest regrows. The importance of soil seed bank for forest regeneration depends also on the age of the forest cut. Allochthonous seeds from remaining patches of forest are needed for forest regeneration as soil seed bank does not store large seeds of shade-tolerant species. Studies quantifying how much woody plant species establishment is regulated by seed stored in soil is essential to understand the real importance of the seed bank for the regeneration of tropical forests.

Acknowledgments - We thank E. Simabukuro and W. Sanders for helpful comments on the manuscript. The text also benefited from comments by anonymous reviewers. Funds were provided by a grant from the Fundação de Amparo à Pesquisa do Estado de São Paulo.

\section{REFERENCES}

ALMEIDA, F. F. M., 1974, Fundamentos geológicos do relevo paulista. Instituto de Geologia e Geografia, Série Teses e Monografias 14, São Paulo.

BAIDER, C., 1994, O banco de sementes e de plântulas na sucessão da Mata Atlântica. Dissertação de Mestrado, Instituto de Biociências, Universidade de São Paulo, São Paulo.

BROWN JR., K. S. \& BROWN, G. G., 1992, Habitat alteration and species loss in Brazilian forests. pp. 129-142. In: T. C. Whitmore \& J. A. Sayer (eds.), Tropical defo restation and species extinction. Chapman \& Hall, London.

COMISSÃO DE SOLOS, 1960, Levantamento de reconhecimento dos solos do Estado de São Paulo. Bol. Serv. Nac. Pesq. Agron., 12: 1-634.

DALLING, J. W., SWAINE, M. D. \& GARWOOD, N. C., 1998, Dispersal patterns and seed bank dynamics of pioneer trees in moist tropical forest. Ecology, 79: 564-578.

DUNCAN, R. S. \& CHAPMAN, C. A., 1999, Seed dispersal and potential forest succession in abandoned agriculture in tropical Africa. Ecology, 9: 998-1.008.

ENRIGHT, N., 1985, Evidence of a soil seed bank under rain forest in New Guinea. Melbourne. Austr. J. Ecol., 10: 6771.

GARWOOD, N. C., 1989, Tropical soil seed banks: a review. pp. 149-209. In: M. A. Leck, V. T. Parker \& R. L. Simpson (eds.), Ecology of soil seed banks. Academic Press, San Diego.

GENTRY, A. H., 1988, Tree species richness of upper Amazonian forests. Proc. Natl. Acad. Sci., 85: 156-159.

GENTRY, A. H. \& EMMONS, L. H., 1987, Geographical variation in fertility, phenology, and composition of the understory of neotropical forests. Biotropica, 19: 216-227.

GÓMEZ-POMPA, A. \& VÁZQUEZ-YANES, C. N., 1981, Successional studies of a rain forest in Mexico. pp. 247266. In: D. C. West, H. H. Schugart \& D. B. Botkin (eds.), Forest concepts and application. Springer-Verlag, New York.

GÓMEZ-POMPA, A., WHITMORE, T. C. \& HADLEY, M., 1991, Tropical rain forest: regeneration and management. Blackwell, New York.

HARTSHORN, G. S., 1978, Treefalls and tropical forest dynamics. pp. 617-638. In: P. B. Tomlinson \& M. H. Zimmermman (eds.), Tropical trees as living systems. Cambridge Univ. Press, New York.

HOLThuiJzen, A. M. A. \& BOERBOOM, J. H. A., 1982, The Cecropia seedbank in the Surinam lowland rain forest. Biotropica, 14: 62-68.

HOPKINS, M. S. \& GRAHAM, A. W., 1983, The composition of soil seed banks beneath lowland tropical rainforests in North Queensland, Australia. Biotropica, 15: $90-99$. 
HOPKINS, M. S. \& GRAHAM, A. W., 1984, Viable soil seed banks in disturbed lowland tropical rainforests in North Queensland, Australia. Melbourne. Austr. J. Ecol., 9: 7179.

HOPKINS, M. S., TRACEY, J. G. \& GRAHAM, A. W., 1990, The size and composition of soil seed banks in remnant patches of three structural rainforest types in North Queensland, Australia. Melbourne. Austr. J. Ecol., 15: 4350 .

KLEIN, R. M., 1980, Ecologia da flora e vegetação do Vale do Itajaí. Sellowia, 32: 165-389.

LAWTON, R. O. \& PUTZ, F. E., 1988, Natural disturbance and gap-phase regeneration in wind-exposed tropical cloud forest. Ecology, 69: 764-777.

LEITÃO FILHO, H. F. (org.), 1993, Ecologia da Mata Atlântica em Cubatão. Editora da Unesp e Editora da Universidade de Campinas, Campinas.

MANTOVANI, W., 1993, Estrutura e dinâmica da floresta Atlântica na Juréia, Iguape, SP. Tese de Livre-docência, Instituto de Biociências, Universidade de São Paulo, São Paulo.

MANTOVANI, W., RODRIGUES, R. R., ROSSI, L., ROAMNIUC-NETO, S., CATHARINO, E. L. M. \& CORDEIRO, I., 1990, A vegetação na Serra do Mar em Salesópolis. pp. 348-384. In: ACIESP (ed.), Proceedings II Simpósio Ecossistemas da Costa Sul e Sudeste: estrutura, composição e manejo. Águas de Lindóia, São Paulo.

MYERS, N., MITTERMEYER, R. A., MITTERMEYER, C. G., FONSECA, G. A. \& KENT, J., 2000, Biodiversity hotspots for conservation priorities. Nature, 403: 853858 .

NASCIMENTO, F. A., 1994, A sucessão secundária inicial na Mata Atlântica, sobre a Serra de Paranapiacaba, Ribeirão Grande, SP. Dissertação de Mestrado, Instituto de Biociências, Univerisdade de São Paulo, São Paulo.

NEPSTAD, D. C., UHL, C. \& SERRÃO, A. S., 1991, Recuperation of a degraded Amazonian landscape: forest recovery and agricultural restoration. Ambio, 20: 248-255.

NEPSTAD, D. C., MOUTINHO, P. R., UHL, C., VIEIRA, I. C. \& SILVA, J. M. C., 1995, The ecological importance of forest remnants in an eastern Amazonian frontier landscape. pp. 133-149. In: J. Schellas \& R. Greenberg (eds.), Forest patches in tropical landscapes. Island Press, London.

NESPTAD, D. C., UHL, C., PEREIRA, C. A. \& CARDOSO, J. M., 1998, Estudo comparativo do estabelecimento de árvores em pastos abandonados e florestas adultas da amazônia oriental. pp. 191-218. In: C. Gascon \& P. Moutinho (eds.), Floresta Amazônica: dinâmica, regeneração e manejo. MCT/INPA, Manaus.

OLIVEIRA, R. R., SAMPAIO, P. D., SILVA, R. F. \& TOFFOLI, D. G., 1994, Roça caiçara, um sistema "primitivo" auto-sustentável. Cienc. Hoje, 18: 44-51.

PIJL, L. van deer, 1982, Principles of dispersal in higher plants. 3. ed. Springer-Verlag, Berlin.
PUTZ, F. E. \& APPANAH, S., 1987, Buried seeds, newly dispersed seeds, and dynamics of a lowland forest in Malaysia. Biotropica, 19: 326-333.

RANTA, P., BROM, T., JOENSUU, E. \& MIKKO, S., 1998, The fragmented Atlantic forest of Brazil: size, shape and distribution of forest fragments. Biodiver. Conserv., 7: 385-403.

REITZ, R. (ed.), 1989, Flora Ilustrada Catarinense. Herbário Barbosa Rodrigues, Itajaí, SC., 149 vol.

RICHARDS, P. W., 1996, The tropical rain forests. Cambridge University Press, London.

ROIZMAN, L. G., 1993, Fitossociologia e dinâmica do banco de sementes de populações arbóreas de floresta secundária em São Paulo. Dissertação de Mestrado, Instituto de Biociências, São Paulo.

ROOSMALEN, G. M. van, 1985, Fruits of the Guianan flora. Institute of Systematic Botany, Utrecht University, Netherlands.

SÃO PAULO, 1972, Atlas pluviométrico do Estado de São Paulo. Secretaria de Serviços e Obras Públicas, São Paulo.

SICK, H., 1997, Ornitologia brasileira. Editora Nova Fronteira, Rio de Janeiro.

SIEGEL, S., 1979, Estatística não-paramétrica. Editora McGraw-Hill do Brasil Ltda., São Paulo.

SILVA, J. C. S., UHL, C. \& MURRAY, G., 1996, Plant succession, landscape management, and the ecology of frugivorous birds in abandoned Amazonian pastures. Conser. Biol., 10: 491-503.

STILES, F. G. \& ROSSELLI, L., 1993, Consumption of fruits of the Melastomataceae: how diffuse is coevolution. Vegetatio, 107/108: 57-73.

SWAINE, M. D. \& WHITMORE, T. C., 1988, On the definition of ecological species groups in tropical rain forest. Vegetatio, 75: 81-86.

TABARELLI, M., 1997, Tese de Doutorado, Instituto de Biociências, Universidade de São Paulo, São Paulo.

TABARELLI, M. \& MANTOVANI, W., 1997, Colonização de clareiras naturais na floresta Atlântica no sudeste do Brasil. Rev. Brasil. Bot., 20: 57-66.

TABARELLI, M. \& MANTOVANI, W., 1999a, A riqueza da floresta Atlântica de encosta no Estado de São Paulo (Brasil). Rev. Brasil. Bot., 22: 217-223.

TABARELLI, M. \& MANTOVANI, W., 1999b, A regeneração de uma floresta tropical montana após corte e queima (São Paulo, Brasil). Rev. Brasil. Biol., 59: 239-250.

TABARELLI, M., VILLANI, J. P. \& MANTOVANI, W., 1993, Aspectos da sucessão secundária no Parque Estadual da Serra do Mar, SP. Rev. Inst. Ftal., 5: 101-114.

UHL, C., 1982, Recovery following disturbances of different intensities in the Amazon rain forest of Venezuela. Interciencia, 7: 19-24.

VALENCIA, R., BALSLEV, H. \& PAZ Y MIÑO, G., 1994, High tree alpha-diversity in Amazonian Ecuador. Biod. Conserv., 3: 21-28. 
VÁZQUEZ-YANES, C. \& OROZCO-SEGOVIA, A., 1987, Fisiología ecológica de semillas en la Estación de Biología Tropical "Los Tuxtlas", Veracruz, México. Rev. Biol. Trop., 35 (supl. 1): 85-89.

VELOSO, H. P., RANGEL-FILHO, A. L. R. \& LIMA, J. C. A., 1991, Classificação da vegetação brasileira, adaptada a um sistema universal. IBGE, Rio de Janeiro.
YOUNG, K. R., EWEL, J. J. \& BROWN, B. J., 1987, Seed dynamics during forest succession in Costa Rica. Vegetatio, 71: 157-173. 